\title{
PENGEMBANGAN LEMBAR KERJA SISWA KIMIA SMA DENGAN MODEL PEMBELAJARAN KOOPERATIF TIPE THINK PAIR SHARE PADA TOPIK ASAM BASA
}

\author{
Firry Abidah ${ }^{1}$, I Nyoman Tika ${ }^{2}$, I Nyoman Selamat ${ }^{3}$ \\ 1,2,3 Universitas Pendidikan Ganesha \\ Singaraja, Indonesia \\ e-mail: firry.abidah@undiksha.ac.id ${ }^{1}$, nyoman.tika@undiksha.ac.id ${ }^{2}$, \\ nyoman.selamat@undiksha.ac.id ${ }^{3}$
}

\begin{abstract}
Abstrak
Penelitian ini bertujuan untuk mengembangkan dan mendeskripsikan lembar kerja siswa (LKS) berbasis model pembelajaran kooperatif tipe Think Pair Share pada topik asam basa sehingga dihasilkan LKS yang valid. Jenis penelitian ini adalah Research and Development (R\&D) menurut Borg and Gall. Penelitian ini dibatasi sampai empat tahap, yaitu 1) penelitian dan pengumpulan informasi, 2) perencanaan, 3) pengembangan rancangan produk, 4) uji coba terbatas. Penelitian ini menghasilkan LKS yang menggunakan model pembelajaran kooperatif tipe Think Pair Share. Hasil penelitian menunjukkan bahwa LKS dengan model pembelajaran kooperatif tipe Think Pair Share layak digunakan untuk pembelajaran kimia topik asam basa. Hal tersebut ditunjukkan oleh: 1) karakteristik LKS dengan model pembelajaran kooperatif tipe Think Pair Share dapat membuat siswa berpikir, menjawab dan berbagi jawaban untuk meningkatkan pola interaksi siswa, 2) Tahap validasi menghasilkan data hasil validasi LKS dengan model pembelajaran kooperatif tipe Think Pair Share pada topik asam basa dari validator ahli dan praktisi dengan nilai rata-rata 3,6 yang menunjukkan kriteria sangat valid, 3) hasil uji keterbacaan yang dilakukan oleh 10 orang siswa terhadap produk LKS dengan model pembelajaran kooperatif tipe Think Pair Share topik asam basa, menunjukkan kriteria sangat baik dengan nilai rata-rata $33 \%$ baik (B) dab $67 \%$ sangat baik (SB).
\end{abstract}

Kata kunci: Asam Basa, Think Pair Share, Penelitian dan Pengembangan

\begin{abstract}
This study aims to develop and describe student worksheets (LKS) based on cooperative learning model type Think Pair Share on acid base topics which a valid worksheet is produced. This type of research using Research and Development (R \& D) according to Borg and Gall. This research is limited to four stages, namely 1) research and information gathering, 2) planning, 3) product design development, 4) limited trials. This study produced LKS using the cooperative pair type Think Pair Share model. The results of the study showed that worksheets with the Think Pair Share cooperative learning model are appropriate to be used in studying chemistryon topic acid base. This is indicated by: (1) the characteristics of LKS with cooperative learning models of the Think Pair Share type can make students think, answer and share answers to improve student interaction patterns, (2) the result of validation student worksheet with
\end{abstract}


Think Pair Share cooperative learning models on acid base topics in terms of professional and practitioner with average rating 3.6 showed that gotten very valid, (3) the results of readability tests conducted by 10 students on LKS products with cooperative learning models of Think Pair Share acid base topics, show criteria very good with value on average $33 \%$ good (B) and $67 \%$ very good (SB).

Keywords: Acid Base, Think Pair Share, Research and Development

\section{PENDAHULUAN}

Ilmu kimia adalah ilmu yang mempelajari tentang suatu materi dan perubahannya (Chang, 2005). Definisi ilmu kimia sebagai materi maka dapat diartikan sebagai ilmu yang mempelajari seluruh hal tentang kehidupan. Pada kenyataannya ilmu kimia dikenal sebagai ilmu yang sulit dipahami oleh siswa. Kesulitan siswa dalam mempelajari konsep dapat menimbulkan kesalahan konsep. Berdasarkan karakteristik materi kimia dalam mempelajari teori-teori dan konsep dasar dapat lebih mudah jika guru menggunakan pendekatan dan model pembelajaran yang tepat. Melalui penggunaan model pembelajaran yang tepat dalam proses pembelajaran diharapkan dapat menciptakan suasana kelas yang kondusif sehingga peserta didik dapat dengan mudah memahami materi yang diajarkan.

Berdasarkan hasil wawancara yang dilakukan penulis pada bulan Januari 2019 kepada salah satu guru bidang kimia di MAN Patas materi asam basa masih dianggap sulit oleh siswa yang dilihat dari $75 \%$ masih banyak siswa yang berada dibawah kriteria ketuntasan minimal (KKM) yaitu $75 \%$. Kesulitan siswa dalam belajar kimia juga disebabkan oleh proses pembelajaran di sekolah yang didominasi dan berpusat pada guru atau lebih dikenal dengan istilah teacher centered. Keadaan ini mengakibatkan siswa masih sering menghafal dan mudah lupa sehingga akan berhimbas pada hasil belajar.

Dalam proses pembelajaran banyak faktor yang memengaruhi hasil belajar siswa. Menurut Triharyanti (2012) terdapat empat komponen penting yang dapat mempengaruhi keberhasilan belajar siswa, yaitu bahan belajar, suasana belajar, media dan sumber belajar, serta guru sebagai subyek pembelajaran. Untuk mencapai tujuan pembelajaran yang baik, guru diharapkan memiliki referensi atau bahan ajar yang baik. Salah satu bahan ajar yang dapat mendukung tercapainya tujuan pembelajaran adalah Lembar Kerja Siswa (LKS). Lembar kerja siswa merupakan salah satu sarana untuk membantu dan mempermudah dalam kegiatan belajar mengajar. Lembar kerja siswa merupakan salah satu bahan ajar yang berupa lembaran kertas yang berisi materi, ringkasan, dan petunjuk-petunjuk pelaksanaan tugas pembelajaran yang harus dikerjakan oleh peserta didik, yang mengacu pada kompetensi dasar yang harus dicapai (Prastowo, 2012).

Salah satu KD yang harus dicapai oleh siswa dalam pembelajaran adalah menganalisis sifat larutan berdasarkan konsep asam basa dan/atau pH larutan (KD 3.1). Untuk mencapai KD tersebut berdasarkan karakteristik ilmu kimia sebagai proses, siswa diajak untuk mengamati suatu wacana berupa fenomena dari materi asam basa. Kegiatan mengamati ini dapat menimbulkan rasa ingin tahu siswa terhadap materi asam basa. Dari kegiatan tersebut siswa diharapkan mampu memunculkan suatu pertanyaan dan menjawabnya.

Model pembelajaran juga mempengaruhi dalam kegiatan pembelajaran. Model pembelajaran kooperatif menekankan adanya kerjasama dalam mencapai tujuan, sehingga pada akhir pembelajaran diharapkan siswa memiliki kemampuan yang baik. Pembelajaran kooperatif selain dapat melatih siswa bekerjasama juga dapat meningkatkan aktivitas siswa dalam pembelajaran (Trinto, 2007).

Model pembelajaran kooperatif tipe Think Pair Share memiliki sintak yang sederhana, yang dapat dilakukan melalui tiga tahapan, yaitu: diawali dari berpikir (think) sendiri tentang pemecahan suatu masalah. Siswa diminta untuk berpasangan (pair) dan mendiskusikan dengan pasangannya mengenai hasil pemikirannya. Setelah diskusi selesai pasangan-pasangan yang ada diminta untuk berbagi (share) dengan pasangan lain tentang apa yang telah diperoleh (Huda, 2014).

Karakteristik bahan ajar yang baik yaitu kesesuaian desain dengan tujuan pembelajaran yang berangkat dari kompetensi dasar, kesesuaian materi dan tujuan pembelajaran, kesesuaian elemen atau unsur dengan tujuan pembelajaran, dan kejelasan penyampaian (Prastowo, 2012). Berdasarkan hasil wawancara pada bulan Januari 2019 kepada salah satu guru bidang kimia di MAN Patas, LKS yang digunakan dalam pembelajaran kimia adalah dari penerbit yang berisi 
ringkasan materi dan kumpulan soal-soal latihan yang belum tentu sesuai dengan tujuan pembelajaran dan latar belakang peserta didik, sehingga tidak memberikan kesempatan kepada siswa untuk menemukan pengetahuannya sendiri. Menurut penelitian yang dilakukan oleh (Sudria, 2016) mayoritas LKS pembelajaran tidak sesuai dengan pendekatan saintifik.

\section{METODE}

Penelitian ini merupakan jenis penelitian dan pengembangan atau Research and Development (R \& D). Menurut (Sugiyono, 2012) penelitian dan pengembangan adalah metode penelitian yang digunakan untuk menghasilkan produk tertentu, dan menguji keefektifan produk tersebut. Penelitian ini dirancang berdasarkan model penelitian pengembangan menurut Borg \& Gall meliputi: (3) penelitian dan pengumpulan informasi, 2) perencanaan, 3) pengembangan rancangan produk, 4) uji coba terbatas, 5) revisi produk utama, 6) uji coba utama, 7) revisi produk operasional, 8) uji coba operasional, 9) revisi produk akhir, dan 10) diseminasi dan implementasi. Pada penelitian dan pengembangan ini terbatas pada tahap uji coba terbatas dikarenakan keterbatasan waktu dan biaya.

Subyek dan obyek pada penelitian ini disesuaikan dengan tahapan Research and Development $(R \& D)$. Subyek pada studi literatur adalah Permendikbud Nomer 24 tahun 2016, buku-buku SMA kelas XI (kurikulum 2013), dan artikel-artikel terkaitpengembangan LKS dengan model pembelajaran kooperatif tipe Think Pair.

Pembuatan produk LKS kimia dengan model pembelajaran kooperatif tipe Think Pair Share. LKS yang dikembangkan terdiri dari bagian pendahuluan yang berisi cover depan, kata pengantar, daftar isi, lembar KI-KD, indikator, serta petunjuk umum penggunaan LKS, bagian isi berisi identitas LKS, tahap permasalahan, merumuskan hipotesis, mengumpulkan data, menganalisis, serta mengambil kesimpulan, bagian penutup berisi daftar pustaka. Pengembangan LKS harus didasarkan pada beberapa aspek, seperti kriteria LKS yang baik dan penyesuaian LKS dengan materi pembelajaran.

Instrumen validasi berupa angket kesesuaian isi, konstruksi, dan uji keterbacaan. Angket yang sudah disusun kemudian divalidasi oleh validator ahli yang bertujuan untuk mengetahui kesesuaian isi materi, indikator, dan KI-KD, kesesuaian konstruksi angket dengan tahapan model pembelajaran kooperatif tipe Think Pair Share, dan untuk mengetahui kesesuaian variasi huruf, ukuran huruf, dan kualitas gambar.

Validasi LKS dilakukan untuk menentukan kevalidan LKS berdasarkan kriteria-kriteria validitas yang telah ditetapkan. Validitas dilakukan oleh 2 orang dosen Jurusan Pendidikan Kimia Undiksha sebagai ahli isi dan media, 2 orang guru kimia sebagai praktisi. Instrumen yang digunakan dalam validasi yaitu lembar validasi. Data hasil validasi dianalisis dengan teknik analisis kualitatif yang dikategorikan ke dalam kategori sangat baik (SB), baik (B), kurang (K), dan sangat kurang (SK). Berdasarkan penilaian tersebut penilaian dapat diketahui aspek-aspek lembar kerja siswa yang sudah memadai dan yang perlu diperbaiki. Data hasil uji keterbacaan dikategorikan ke dalam empat kategori, yakni sangat baik (SB), baik (B), kurang (K), sangat kurang (SK). Data hasil uji keterbacaan dianalisis dengan mendeskripsikan rata-rata persentase siswa yang memberikan tanggapan pada masing-masing aspek yang telah dinilai.

\section{HASIL DAN PEMBAHASAN}

Hasil penelitian pada tahap analisis kebutuhan terdiri atas studi literatur dan studi lapangan. Hasil dari studi literatur diperoleh hasil analisis Kompetensi Inti (KI), Kompetensi Dasar $(\mathrm{KD})$, silabus, dan sumber-sumber buku serta artikel yang terkait dalam penelitian. Hasil yang diperoleh yakni acuan penyusunan LKS dengan model pembelajaran kooperatif tipe Think Pair Share pada topik asam basa.

Hasil yang diperoleh dari studi lapangan yaitu hasil wawancara kepada salah satu guru kimia dari sekolahan MAN Patas untuk mengetahui pendapat guru mengenai lembar kerja siswa kimia kelas XI yang digunakan disekolah. Dari hasil wawancara yang sudah dilakukan diperoleh bahwa lembar kerja siswa yang disekolah masih kurang jelas, dan masih belum menuntun siswa dalam menemukan jawaban sendiri. Hasil wawancara juga menunjukkan bahwa guru belum pernah membuat lembar kerja siswa dengan model pembelajaran kooperatif tipe Think Pair Share, sehingga pengembangan lembar kerja siswa berbasis model pembelajaran kooperatif tipe Think Pair Sahre sangat penting untuk dikembangkan. 
Pada tahap perencanaan mengembangankan produk lembar kerja siswa kimia SMA dengan model pembelajaran kooperatif tipe Think Pair Share pada topik asam basa. Pada tahap perencanaan langkah yang dilakukan adalah mengidentifikasi isi materi dari analisis silabus, dan perencanaan uji validasi produk. Lembar kerja siswa pada topik asam basa dibuat untuk memastikan keselaraan setiap langkah-langkah dari sintak model pembelajaran TPS pada lembar kerja siswa yang dikembangkan.

Pada tahap pembuatan produk awal dilakukan penyusunan draf kasar lembar kerja siswa kimia SMA/MA pada materi asam basa. lembar kerja siswa yang dikembangkan terdiri atas pendahuluan, isi dan penutup. Bagian pendahuluan berisi prakata, kompetensi inti, kompetensi dasar, indikator pembelajaran, dan daftar isi. Bagian isi berisi tujuan pembelajaran, petunjuk kerja, dan Bagian penutup berisi daftar pustaka.

Setelah LKS disusun, LKS diuji kualitasnya melalui validasi ahli isi, seorang ahli media, dan 2 (dua) orang praktisi, 1 (satu) dosen ahli bahasa, serta diuji keterbacaannya oleh 10 (sepuluh) siswa SMA dari MAN Patas. Hasil penilaian validator dapat dilihat pada Tabel 1.

Tabel 1. Hasil Penilaian Validator

\begin{tabular}{lc}
\hline Aspek yang dinilai & Rata-rata \\
\hline Kelayakan isi & 3,40 \\
Karakteristik model TPS & 3,37 \\
Komponen penyajian & 3,83 \\
Kebahasaan & 3,70 \\
Kegrafikan & 3,67 \\
Skor rata-rata & 3,6 \\
\hline
\end{tabular}

Berdasarkan penilaian validator dan praktisi memberikan nilai baik dan sangat baik. Ratarata hasil validasi lembar kerja siswa dengan model pembelajaran kooperatif tipe TPS adalah 3,66 yang menunjukkan criteria sangat valid.

Setelah LKS divalidasi kemudian diuji keterbacaannya terhadap 10 siswa MAN Patas. Hasil penilaian tingkat keterbacaan dapat dilihat pada Tabel 2:

Tabel 2. Hasil Penilaian uji keterbacaan

\begin{tabular}{clcccc}
\hline No & Aspek ang dinilai & SK & K & B & SB \\
\hline 1 & Judul LKS sesuai dengan materi asam basa & 0 & 0 & 4 & 6 \\
2 & $\begin{array}{l}\text { Saya mudah memahami pendahuluan yang } \\
\text { disajikan pada LKS }\end{array}$ & 0 & 0 & 2 & 8 \\
3 & $\begin{array}{l}\text { Kolom dalam LKS dapat memudahkan saya } \\
\text { untuk menulis jawaban } \\
\text { pertanyaan }\end{array}$ & 0 & 0 & 2 & 8 \\
$4 \quad \begin{array}{l}\text { Saya mudah memahami pertanyaan yang } \\
\text { ada } \\
\text { pada } \\
\text { LKS }\end{array}$ & 0 & 0 & 2 & 8 \\
5 & $\begin{array}{l}\text { Petunjuk yang ada dalam LKS jelas dan } \\
\text { mudah saya pahami }\end{array}$ & 0 & 0 & 4 & 6 \\
$6 \quad \begin{array}{l}\text { Tidak terdapat salah pengetikan dalam LKS } \\
\text { Bahasa yang digunakan jelas mudah } \\
\text { dan } \\
\text { dimen } \\
\text { gerti sehingga } \\
\text { mengerjakan LKS Asam Basa dengan } \\
\text { model Think Pair }\end{array}$ & 0 & 0 & 6 & 4 \\
Share
\end{tabular}


- Ukuran huruf yang digunakan jelas

9 Tampilan pada LKS tidak membosankan

10 Bahasa yang digunakan sederhana dan mudah untuk dimengerti
0

0

0
0

0

0
3

7

$4 \quad 6$

9

\begin{tabular}{ccccc}
\hline Rata-rata skor & 0,0 & 0,0 & 3,3 & 6,7 \\
\hline Prosentase (\%) & 0 & 0 & 33 & 67 \\
\hline
\end{tabular}

Uji keterbacaan menunjukkan bahwa keterbacaan lembar kerja siswa yang dikembangkan sudah baik. Rata-rata keterbacaan lembar kerja siswa adalah $33 \%$ baik dan $67 \%$ sangat baik. Hal ini menunjukkan bahwa lembar kerja siswa kimia SMA/MA dengan model pembelajaran kooperatif tipe Think Pair Share pada topik teori asam basa secara umum sudah dapat dipahami oleh siswa. Penilaian, pendapat, komentar, dan saran yang diberikan oleh validator bersifat kontruktif guna menyempurnakan lembar kerja siswa yang dikembangkan. Hal tersebut mengidikasikan bahwa lembar kerja siswa kimia SMA dengan model pembelajaran kooperatif tipe Think Pair Share pada topik teori asam basa memiliki validitas yang memadai. Validitas lembar kerja siswa kimia SMA dengan model pembelajaran kooperatif tipe Think Pair Share pada topik teori asam basa ini tergolong baik berdasarkan hasil validasi ahli dan praktisi.

\section{SIMPULAN DAN SARAN}

Berdasarkan hasil penelitian dan pembahasan, dapat disimpulkan bahwa karakteristik dari LKS kimia SMA menggunakan sintak pembelajaran koooperatif tipe Think Pair Share pada topik asam basa yang dikembangkan dapat memberikan kesempatan kepada peserta didik untuk bekerja sendiri, mampu mengoptimalkan partisipasi peserta didik, mampu memberikan kesempatan lebih banyak kepada setiap peserta didik untuk menunjukkan partisipasinya, dan dapat membangkitkan pola interaksi siswa. Lembar kerja siswa (LKS) berbasis model pembelajaran kooperatif tipe Think

Bagi Guru dapat menggunakan lembar kerja siswa kimia SMA kelas XI berbasis model pembelajaran kooperatif tipe Think Pair Share pada topik asam basa yang dikembangkan ini dapat digunakan sebagai alat bantu untuk menunjang proses belajar mengajar dikelas. Guru juga dapat mengikuti tahapan penelitian dan pengembangan ini dalam merancang LKS yang akan diberikan di kelas seperti membuat analisis model pembelajaran yang akan digunakan dalam validator bersifat kontruktif guna menyempurnakan lembar kerja siswa yang dikembangkan. Hal tersebut mengidikasikan bahwa lembar kerja siswa kimia SMA dengan model pembelajaran kooperatif tipe Think Pair Share pada topik teori asam basa memiliki validitas yang memadai. Validitas lembar kerja siswa kimia SMA dengan model pembelajaran kooperatif tipe Think Pair Share pada topik teori asam basa ini tergolong baik berdasarkan hasil validasi ahli dan praktisi. Pair Share pada topik asam basa dari segi aspek kelayakan yang meliputi aspek kelayakan isi, penyajian, kebahasaan, dan kegrafikan dikategorikan sangat baik (SB) dengan hasil penilaian rata-rata 3,6 dan/atau sangat layak digunakan sebagai bahan ajar pembelajaran. Hasil rata-rata uji keterbacaan LKS kimia berbasis model pembelajaran kooperatif tipe Think Pair Share pada topik asam basa adalah $33 \%$ baik (B) dan $67 \%$ sangat baik (SB). Hal ini menunjukkan bahwa LKS yang dikembangkan secara umum sudah baik untuk dipahami oleh siswa. proses belajar mengajar yang berpendekatan saitifik sesuai dengan yang diamanatkan kurikulum 2013, sehingga kegiatan pembelajaran yang dilakukan oleh guru dan siswa di kelas dapat dilaksanakan secara optimal dan sesuai dengan tujuan pembelajaran. Bagi peneliti lain penelitian ini baru dilakukan sampai tahap uji coba terbatas, perlu adanya penelitian lebih lanjut terutama sampai tahap akhir yaitu pada tahap desiminasi kebutuhan, perencanaan, pengembangan produk awal, validasi produk ahli dan praktisi serta uji keterbacaan. 
Vol. 2, No. 1, 2018

\section{DAFTAR RUJUKAN}

Borg, W. L., \& Gall, M. D. 1989. Educational Research: Sn Introduction. New York: Long Man.

Hilmina. 2011. Upaya Meningkatkan Hasil Belajar Kimia Siswa dengan Model Discovery Learning melalui Kegiatan Laboratorium pada Konsep Sistem Koloid (Penelitian Tindakan Kelas di Huda, M. 2014. Model-model Pembelajaran. Yogyakarta: Pustaka Pelajar.

Prastowo, A. 2012. Panduan kreatif membuat bahan ajar. Yogyakarta: Penerbit Diva Pres.

Sudria, I. B. 2006. Peningkatan Kualitas Konsepsi Mahasiswa tentang Konsep konsep Dasar Kimia Melalui Optimalisasi Pengaitan Aspep Makroskopik, Mikroskopik.

Trianto. 2010. Model Pembelajaran Terpadu: Konsep, Strategi dan Implementasinya dalam Kurikulum Satuan Pendidikan (KTSP). Jakarta: Bumi Aksara. 